ISSN 2080-5993

e-ISSN 2449-9811

\title{
Adam Zaremba
}

Uniwersytet Ekonomiczny w Poznaniu

e-mail: adam.zaremba@ue.poznan.pl

\section{Szymon Okoń}

Uniwersytet Ekonomiczny w Poznaniu

szymon.okon@ue.poznan.pl

\section{EMISJE AKCJI A OCZEKIWANE STOPY ZWROTU NA RYNKACH GLOBALNYCH*}

\section{SHARE ISSUANCE AND THE EXPECTED RETURNS IN INTERNATIONAL EQUITY MARKETS}

DOI: 10.15611/nof.2016.3.07

JEL Classification: G11, G12, G15

\begin{abstract}
Streszczenie: Zarówno naukowcy, jak i praktycy rynku giełdowego często traktują aktywność w zakresie pierwszych ofert publicznych (IPO) jako wyznacznik nastrojów inwestorów i wyceny rynku. W niniejszym opracowaniu zbadano tę koncepcję na poziomie krajowym. W badaniu wykorzystano sortowanie i testy przekrojowe, aby przyjrzeć się relacji pomiędzy emisjami akcji a przyszłymi stopami zwrotu w 78 krajach w latach 1995-2015. Autorzy wykazali występującą w różnych krajach negatywną korelację w odniesieniu do emisji akcji i kształtowania się przyszłych stóp zwrotu. Rynki z dużą aktywnością w zakresie emisji akcji w przeszłości cechują się zdecydowanie niższymi stopami zwrotu niż rynki z mniejszą aktywnością w tym zakresie. Zjawisko to występuje ze szczególnym nasileniem na mniejszych rynkach, nie ma natomiast znaczenia na rynkach większych.
\end{abstract}

Słowa kluczowe: emisja akcji, pierwsze oferty publiczne (IPO), prognozowanie stóp zwrotu, anomalie giełdowe, inwestycje międzynarodowe, analiza przekrojowa stóp zwrotu.

Summary: Practitioners and academics often consider IPO activity as a gauge of investor optimism and market valuation. This study investigates the cross-sectional implications of this concept at the country level. We use sorting and cross-sectional tests to examine linkages between past share issuance and future returns across 78 countries for the years 1995-2015. We find convincing and robust evidence that the share issuance is negatively related to future returns across countries. Markets with high past stock issuance markedly underperform markets with low stock issuance. This phenomenon is particularly strong in small countries, but insignificant across large ones.

Keywords: share issuance, initial public offerings (IPO), return predictability, stock market anomalies, international investments, cross section of stock returns.

* Badanie zostało sfinansowane z grantu NCN „Decyzje finansowe w spółkach giełdowych na nieefektywnym rynku kapitałowym” (nr projektu DEC-2013/09/B/HS4/01335). 


\section{Wstęp}

Ogólnorynkowa aktywność związana z pierwszymi ofertami publicznymi (IPO) jest często postrzegana przez uczestników giełdy jako wyznacznik optymizmu inwestorów. Duża liczba IPO i istotne emisje mogą być przejawem nadmiernego optymizmu i zawyżonej wyceny akcji, natomiast IPO sporadyczne i małe emisje akcji mogą wskazywać na nastroje przeciwne. Pogląd ten uzasadniają liczne badania nad zjawiskami powiązanymi z pierwszymi ofertami publicznymi. Lee i in. [1991] oraz Lowry [2003] wykazali zbieżność okresów dużej aktywności na rynku IPO z niskim dyskontem w notowaniach funduszy inwestycyjnych zamkniętych, co autorzy uznają za miernik nastrojów inwestorów. Dorn [2009] dokumentuje kluczowy wpływ nastrojów inwestorów na detaliczny popyt na akcje emitowane w ramach IPO. Ljungqvist i in. [2006] opracowali model, w którym częstotliwość IPO i osiągane stopy zwrotu z akcji po IPO przypisuje się wahaniom nastrojów inwestorów. Zjawisko korelacji między nastrojami na rynku, IPO i wycenami akcji opisuje również Campbell $\mathrm{i}$ in. [2008].

Celem niniejszego artykułu jest sprawdzenie przekrojowych implikacji powyższych zjawisk i przyjrzenie się powiązaniom między emisją akcji a kształtowaniem się przyszłych stóp zwrotu w różnych krajach. Autorzy stawiają następującą hipotezę: jeśli aktywność w zakresie emisji akcji na rynku jest wskaźnikiem nastrojów inwestorów i potencjalnej zawyżonej lub zaniżonej wyceny, można jej użyć do prognozowania stóp zwrotu na międzynarodowych rynkach akcji w ujęciu przekrojowym. Ujmując rzecz inaczej, należy stwierdzić, że rynki o dużej aktywności w zakresie emisji akcji są postrzegane jako wyceniane zbyt wysoko i w związku z tym charakteryzują się niskimi przyszłymi stopami zwrotu. $Z$ drugiej strony, niewielka ogólnorynkowa aktywność w zakresie IPO jest potencjalnie przejawem zbyt niskiej wyceny i wysokich stóp zwrotu w przyszłości. W związku z tym autorzy oczekują, że rynki o niskiej aktywności w zakresie emisji akcji będą uzyskiwać wyniki lepsze niż rynki o wysokiej aktywności.

Zjawisko badane w niniejszym opracowaniu może być powiązane z szeregiem innych anomalii giełdowych związanych z IPO. Baker i Wurgler [2000] zaobserwowali, że udział emisji akcji w nowych emisjach jest lepszym prognostykiem w zakresie kształtowania się rocznych stóp zwrotu niż wskaźnik dywidendy do ceny lub wartości księgowej do rynkowej. Spostrzeżenie to potwierdzają również Pontiff i Woodgate [2008], którzy wykazali, że emisje akcji cechują się lepszą przekrojową zdolnością przewidywania przyszłych stóp zwrotu z akcji niż inne popularne wskaźniki, takie jak wartość księgowa do rynkowej, wielkość czy momentum. Dowody na potwierdzenie powyższego znaleźli również Greenwood i Hanson [2012].

Z koncepcji autorów, której osią jest założenie, że wskutek zjawisk behawioralnych spodziewane stopy zwrotu $\mathrm{z}$ krajowych rynków akcji są negatywnie skorelowane z wcześniejszą aktywnością na rynku IPO, można wyciągnąć dodatkowy interesujący wniosek. Jeśli bowiem jednym z czynników wpływających na ten efekt jest międzynarodowa mobilność kapitału, która zapobiega likwidowaniu 
różnic cenowych między rynkami w drodze arbitrażu, wpływ aktywności w zakresie emisji powinien być silniejszy, gdy mobilność ta jest ograniczona. W związku z tym autorzy stawiają hipotezę, że relacje pomiędzy emisją akcji i kształtowaniem się przyszłych stóp zwrotu powinny być słabsze w krajach dużych i rozwiniętych, o płynnych rynkach niż w krajach małych. W niniejszym opracowaniu zbadano bezpośrednio właśnie te powiązania.

Niniejsze badanie ma na celu wniesienie dwojakiego wkładu do literatury. Po pierwsze, autorzy badają występujące na poziomie krajowym powiązania między aktywnością na rynku IPO (pierwszych emisji publicznych, Initial Public Offerings) i przyszłymi stopami zwrotu. Dodatkowo przedmiotem badania jest również to, czy zjawisko to występuje z równym nasileniem na rynkach dużych i małych. W związku z tym zbadano wyniki portfeli posortowane pojedynczo i podwójnie według modeli wyceny aktywów na poziomie krajowym, korzystając z próby obejmującej dane z 78 krajów za lata 1999-2015.

Drugą motywacją stojącą za badaniem jest udostępnienie globalnym inwestorom nowych narzędzi. Rosnąca integracja i otwartość globalnych rynków finansowych spowodowały zwiększenie korelacji między stopami zwrotu z rynków akcji w różnych krajach [Bekaert, Harvey 2000; Quinn, Voth 2008] i tym samym wyraźnie mniejsze korzyści z dywersyfikacji inwestycji w skali międzynarodowej [Goetzmann $\mathrm{i}$ in. 2005]. W związku z tym w procesie inwestowania jeszcze bardziej na znaczeniu zyskały strategie selekcji kraju [Hester 2013], co zbiegło się z szeroką dostępnością pasywnych produktów inwestycyjnych dających łatwy dostęp do rynków międzynarodowych: kontraktów futures, funduszy indeksowych i funduszy typu ETF. Mimo rozległych możliwości i dużych rozmiarów globalnego rynku ETF zestaw narzędzi dostępnych dla inwestujących w ETF nadal wydaje się ograniczony. Jednocześnie inwestujący w pojedyncze akcje mogą korzystać z bogatej literatury na temat analizy rozkładów przekrojowych i czasowych. Na przykład w najnowszych artykułach Jacobs [2015] zbadał 100 anomalii w odniesieniu do akcji, a Harvey i in. [2015] wymienili ponad 300 odkrytych czynników wyceny aktywów. W przeciwienstwie do tej dziedziny pole pasywnych funduszy ETF i innych produktów indeksowych jest jeszcze w dużej mierze niezbadane. Autorzy mają nadzieję, że niniejsze badanie stanowić będzie krok na drodze do uzupełnienia tych braków.

Kluczowe wnioski z badania można podsumować następująco. Rynki z wysoką aktywnością w zakresie IPO w przeszłości cechują się zdecydowanie niższymi stopami zwrotu niż rynki, na których aktywność ta jest niska. Uzyskane wyniki są odporne na zmiany w okresie formowania portfela oraz waluty bazowej. Niemniej jednak siła powiązania pomiędzy stopami zwrotu a emisjami akcji jest różna na rynkach o różnej kapitalizacji. Na rynkach małych efekt ten jest bardzo silny, na dużych zaś nie ma większego znaczenia. 


\section{Dane źródlowe i metody badawcze}

Celem niniejszego badania jest przetestowanie wyników portfeli krajowych utworzonych według danych o emisji akcji. W niniejszej części autorzy przedstawili źródła danych i procedury używane przy ustalaniu składu portfeli, a także zastosowane modele wyceny aktywów i metody testowe.

\section{1. Źródła danych i ich wstępne przygotowanie}

Niniejsze badanie przeprowadzone zostało na podstawie stóp zwrotu z indeksów międzynarodowych rynków akcji z 78 krajów ${ }^{1}$. Wszystkie dane źródłowe zostały pobrane z bazy danych Bloomberg. W badaniu wykorzystano miesięczne szeregi czasowe, dające liczbę obserwacji wystarczającą do zapewnienia skuteczności testów i uniknięcia nadmiernej ekspozycji na problemy mikrostrukturalne [de Moor, Sercu 2013]. Dla wszystkich krajów autorzy przyjęli indeksy MSCI, chcąc zastosować jednolitą metodologię obliczania stóp zwrotu. Indeksy MSCI to indeksy referencyjne akcji ważone kapitalizacją, szeroko stosowane w skali ogólnoświatowej. Dodatkowo indeksy te stanowią podstawę licznych kontraktów futures i ponad 650 funduszy ETF z całego świata ${ }^{2}$. Stąd też decyzja autorów o zastosowaniu indeksów MSCI w celu dopasowania badania do praktyki inwestycyjnej. Ustalanie indeksów i zarządzanie nimi następuje pod kątem zapewnienia pełnej możliwości inwestowania przez międzynarodowych inwestorów instytucjonalnych [MSCI 2014a]. Indeksy obejmują około $85 \%$ kapitalizacji rynku akcji w krajach, które reprezentują [MSCI 2014b]. Jeśli indeks MSCI nie jest dostępny dla danego kraju, w drugiej kolejności posłużono się indeksem Dow Jones, a w trzeciej STOXX.

Stopy zwrotu obliczono na podstawie ważonych kapitalizacją indeksów opartych na stopie zwrotu netto, co oznacza, że poddano je korekcie o działania korporacyjne spółek (podział i scalenie akcji, prawa poboru itd.) i gotówkę wypłacaną inwestorom (dywidendy). Zaprezentowanie indeksów w wartościach netto oznacza, że dywidendy obliczane są po potrąceniu podatku. Autorzy zastosowali powyższe podejście, chcąc uwzględnić efekt różnych stawek podatku od dywidendy w poszczególnych krajach. Badanie obejmuje okres od stycznia 1999 do lutego 2015, stosownie do dostępności danych (194 obserwacje miesięczne). Łącznie próba badawcza obejmuje

${ }^{1}$ Arabia Saudyjska, Argentyna, Australia, Austria, Bahrajn, Bangladesz, Belgia, Brazylia, Bułgaria, Chile, Chiny, Chorwacja, Cypr, Czechy, Dania, Egipt, Estonia, Filipiny, Finlandia, Francja, Grecja, Hiszpania, Holandia, Hongkong, Indie, Indonezja, Irlandia, Islandia, Japonia, Jordania, Kanada, Katar, Kazachstan, Kenia, Kolumbia, Korea Południowa, Kuwejt, Liban, Litwa, Luksemburg, Łotwa, Malezja, Malta, Maroko, Mauritius, Meksyk, Niemcy, Nigeria, Norwegia, Nowa Zelandia, Oman, Pakistan, Peru, Polska, Portugalia, Rosja, RPA, Rumunia, Serbia, Singapur, Sri Lanka, Słowenia, Stany Zjednoczone, Szwajcaria, Szwecja, Tajlandia, Tajwan, Trynidad i Tobago, Tunezja, Turcja, Ukraina, Wenezuela, Węgry, Wielka Brytania, Wietnam, Włochy, ZEA.

${ }^{2}$ Dane z http://www.msci.com/products/indexes/ [dostęp 1 listopada 2014]. 
78 krajowych rynków akcji. Wykorzystano indeksy zarówno istniejące, jak i wstrzymane (np. MSCI Wenezuela), aby uniknąć jakiejkolwiek postaci błędów selekcji danych (survivorship bias). Dany rynek akcji jest uwzględniany w próbie badawczej $\mathrm{z}$ miesiąca $t$, jeśli można ustalić: kapitalizację tego rynku na koniec miesiąca $t-1$, emisję akcji na rynku w okresie tworzenia portfela (poprzedni okres 1-24 miesiące) i stopę zwrotu w miesiącu $t$.

Początkowo wartości indeksów i kapitalizacji uwzględniane były w walutach lokalnych, później autorzy podzielili jednak pogląd wyrażony przez Liew i Vassalou [2000] oraz Bali i in. [2013], a mianowicie że porównania dokonywane w różnych walutach mogą być mylące. Taka sytuacja występuje zwłaszcza na rynkach wschodzących i granicznych, gdzie inflacja i stopy wolne od ryzyka są niekiedy bardzo wysokie i różnią się pomiędzy poszczególnymi rynkami. Z tego powodu zastosowano podejście przyjęte przez Liu i in. [2011], Bekaerta i in. [2007] lub Browna $\mathrm{i}$ in. [2008], to jest denominowanie wszystkich danych w dolarach amerykańskich celem osiągnięcia zbiorczych wyników w skali międzynarodowej. Aby konsekwentnie stosować powyższą zasadę denominacji w dolarach, w badaniu nadwyżkowe stopy zwrotu obliczone zostały na podstawie jednomiesięcznej stopy amerykańskich bonów skarbowych z bazy Bloomberga.

Celem niniejszego badania jest przetestowanie wyników portfeli krajowych utworzonych według danych o emisji akcji. W niniejszej części autorzy przedstawili źródła danych i procedury używane przy ustalaniu składu portfeli, a także zastosowane modele wyceny aktywów i metody testowe.

\subsection{Badane portfele}

W niniejszym artykule autorzy zbadali wyniki portfeli krajowych utworzonych na podstawie danych o emisji akcji w ciągu ostatnich 12 miesięcy. Innymi słowy, okresy formowania portfeli rozpoczynały się w miesiącu $t-12$ i kończyły w miesiącu $t-1$. Autorzy najpierw obliczyli dla każdego miesiąca współczynnik emisji na rynku akcji jako stosunek łącznej wartości rynkowej wszystkich akcji wyemitowanych w tym czasie na danym rynku do łącznej kapitalizacji rynku akcji według reprezentatywnego wskaźnika MSCI z początku miesiąca. Następnie wyliczono średnią z szeregu czasowego współczynników emisji w ciągu całego okresu formowania równego 12 miesięcy. Wreszcie na koniec każdego miesiąca $t-1$ uporządkowano wszystkie indeksy rynków akcji według średniej współczynników emisji w okresie formowania. Dalej zdefiniowano punkty graniczne (breakpoints) w postaci 20, 4060 i 80 percentyla i w ten sposób utworzono pięć podgrup. W ostatnim kroku w poszczególnych podgrupach utworzono portfele równoważone indeksów (equally weighted). Stosowanie równoważonych indeksów do tworzenia portfeli jest powszechną praktyką w badaniach na poziomie kraju, gdyż przyjmuje się, że można to łatwo osiągnąć np. płynnymi kontraktami futures lub funduszami ETF. Inaczej rzecz ujmując, należy stwierdzić, że podejście to zdaje się bardziej pasować do prakty- 
ki inwestycyjnej i perspektywy inwestora (zob. np. [Asness i in. 2013]). Następnie dodano portfele różnicowe, tj. zerowe, będące portfelami long/short: $100 \%$ pozycji długiej w kwintylu rynków o najniższym współczynniku emisji i 100\% pozycji krótkiej w kwintylu rynków o najwyższym współczynniku emisji.

Przy obliczaniu stóp zwrotu z portfeli autorzy najpierw przekrojowo zagregowali arytmetyczne stopy zwrotu, tworząc portfele, a następnie przekształcili je na logarytmiczne stopy zwrotu w celu umożliwienia wnioskowania statystycznego.

\subsection{Ocena stóp zwrotu}

Badanie portfeli międzynarodowych z wielu krajów wymaga zastosowania właściwego modelu wyceny aktywów. Model ten powinien być zbieżny z perspektywą międzynarodowego inwestora, którego motywacją jest inwestowanie w instrumenty oparte na zagranicznych indeksach, np. ETF lub kontrakty futures. Dodatkowo odpowiedni model wyceny powinien zawierać mechanizmy kompensujące międzyrynkowe efekty wyceny aktywów, które mogą thumaczyć zmienność stóp zwrotu. Dlatego też autorzy zastosowali model czteroczynnikowy na poziomie kraju ${ }^{3}$. Model ten jest identyczny z modelem zaproponowanym przez Carharta [1997], z tym że wszystkie czynniki wyceny aktywów oparte są na stopach zwrotu z indeksów MSCI rynków akcji. Innymi słowy, autorzy faktycznie sprawdzają, czy strategie wyboru rynków akcji na podstawie długoterminowych stóp zwrotu poszerzają granicę inwestora inwestującego w indeksy międzynarodowe z ekspozycją na anomalie krajowego poziomu rynku, wartości, wielkości i momentum ${ }^{4}$. Za powyższe cztery efekty w modelu Carharta odpowiadają odpowiednio cztery czynniki wyceny aktywów: ryzyko rynkowe $(M k t-R f)$, wysokie minus niskie $(H M L)$, małe minus duże $(S M B)$ i zwycięzcy minus przegrani $(W M L)$.

Ryzyko rynkowe obliczane jest jako nadwyżkowa stopa zwrotu powyżej stopy wolnej od ryzyka dla ważonego kapitalizacją portfela utworzonego z indeksów wszystkich krajów w próbie badawczej. Aby obliczyć trzy pozostałe czynniki przekrojowe $(H M L, S M B$ i $W M L)$, indeksy w momencie $t-1$ zostały posortowane według stosunku wartości księgowej do rynkowej $(\mathrm{B} / \mathrm{M})^{5}$, rozmiaru (łącznej kapitalizacji rynku akcji) i momentum (opóźnionej skumulowanej stopy zwrotu z okresu $t-12$ do $t-1)$. Stopy zwrotu uzyskano po ich posortowaniu w układzie $2 \times 3$ według rozmiaru i B/M oraz rozmiaru i momentum. Rynki małe i duże zostały zdefiniowa-

${ }^{3}$ Model ten zastosowano początkowo w artykułach Zaremby [2015a; 2015b]. Autorzy ściśle trzymają się tego podejścia.

${ }^{4}$ Jak dotąd, w odniesieniu do indeksów krajowych rynków udokumentowane zostały trzy z powyższych czynników: wielkość przez Kepplera i Trauba [1993] oraz Kepplera i Encinosa [2011], wartość przez Macedo [1995] i Kima [2012] oraz momentum przez Balversa i Wu [2006] oraz Bhojraja i Swaminathana [2006].

${ }^{5}$ Wskaźnik $B / M$ jest zawsze opóźniony o cztery miesiące celem uniknięcia tzw. odchylenia lookahead bias. 
ne jako rynki z kapitalizacją odpowiednio powyżej lub poniżej wartości mediany w miesiącu $t-1$. Punktami granicznymi wartości $B / M$ w sortowaniu $2 \times 3$ są wartości 30 i 70 percentyla $\mathrm{B} / \mathrm{M}$ dla wszystkich indeksów w miesiącu $t-1^{6}$. Niezależne sortowania w układzie $2 \times 3$ według rozmiaru i $B / M$ dają sześć portfeli $-S G, S N, S V, B G$, $B N$, i $B V$, gdzie $S$ i $B$ oznaczają rynki małe i duże, a $G, N$, i $V$-spółki wzrostowe, neutralne i wartościowe (odpowiednio 30\% najniższych, $40 \%$ środkowych i $30 \%$ najwyższych wartości $B / M$ ). Kolejnym etapem jest obliczenie miesięcznych stóp zwrotu ważonych kapitalizacją dla wszystkich sześciu portfeli. Stopy zwrotu w miesiącu $t-1$ dla czynnika $S M B$ obliczane są jako równoważona średnia stóp zwrotu dla trzech portfeli małych krajów z sortowania z układu $2 \times 3$ według wielkości i $B / M$ minus średnia stóp zwrotów dla trzech portfeli dużych krajów. Stopa zwrotu dla czynnika wartość, $H M L$, stanowi różnicę między równoważonymi stopami zwrotu z portfeli wartościowych $(B V, S V)$ oraz równoważonymi stopami zwrotu z portfeli wzrostowych $(B G, S G)$. Sortowanie $2 \times 3$ według wielkości i momentum zostało przeprowadzone w ten sam sposób co sortowanie według wielkości i $B / M$, z tym że wskaźnik $B / M$ zastąpiony został opóźnionym momentum stopy zwrotu. W przypadku portfeli utworzonych na końcu miesiąca $t-1$ opóźnione momentum stopy zwrotu jest skumulowaną stopą zwrotu z akcji za miesiące $t-12$ do $t-2$. Autorzy stosują metodę zaproponowaną przez Famę i Frencha [2012] i pomijają miesiąc sortowania, co jest standardowym sposobem unikania w testach momentum zjawiska odwrócenia w krótkim okresie (short-term reversal). Punkty graniczne momentum użyte zostały do stworzenia układu $2 \times 3$, identycznego jak w przypadku HML. Stopa zwrotu WML w miesiącu $t$ obliczana jest jako różnica między równoważoną średnią stóp zwrotu dużych i małych indeksów zwycięzców $(S W, B W)$ oraz równoważoną średnią stóp zwrotu dużych i małych indeksów przegranych $(S L, B L)$.

Wszystkie parametry regresji zostały oszacowane zwykłą metodą najmniejszych kwadratów (OLS) zgodnie z uwagami Cochrane [2001], gdzie uznano ją za w większości wypadków bardziej właściwą niż na przykład $G L S$. Dodatkowo statystyki $t$ odpowiadające parametrom zostały oszacowane metodą bootstrap (bootstrap standard errors), tak aby uniknąć przyjmowania jakichkolwiek założeń dotyczących rozkładu. Dodatkowo, w celu ustalenia, czy stałe regresji w grupie portfeli statystycznie różnią się od zera, poddano je ocenie powszechnie stosowaną metodą statystyczną GRS zasugerowaną przez Gibbonsa i in. [1989]. Hipotezą zerową testu jest przyjmowanie przez wszystkie (pięć) wyrazów wolnych wartości 0 , a hipotezą alternatywną przyjmowanie wartości odmiennej.

Słabą stroną testu statystycznego GRS jest fakt, że uzyskane wyniki nie biorą pod uwagę przekrojowej struktury ponadprzeciętnych stóp zwrotu, a jedynie ich wartości. Stąd też w celu przetestowania, czy nadwyżkowe stopy zwrotu (lub wy-

\footnotetext{
${ }^{6}$ Aby obliczyć ten wskaźnik na poziomie indeksu, autorzy najpierw zagregowali wartości księgowe wszystkich spółek, przypisując im wagi według określonej metodologii indeksów, a następnie podzielili uzyskaną sumę przez łączną kapitalizację rynku akcji wszystkich spółek w danym indeksie.
} 
razy wolne z modeli regresji) systematycznie rosną wraz ze spadkiem przeszłych długookresowych stóp zwrotu, wykonano również test relacji monotonicznej (MR) wprowadzony przez Pattona i Timmermanna [2010]. Jest to test symulacyjny, w którym hipotezą bazową jest brak rozkładu monotonicznego w przekroju nadwyżkowych stóp zwrotu lub stałych regresji (ich wartości nie rosną w miarę spadku aktywności na rynku IPO), a hipotezą alternatywną istnienie takiego rozkładu. Procedura testowa została szczegółowo opisana w pracy Pattona i Timmermana [2010]. Każdy test MR w niniejszym artykule bazował na 10000 losowań i został zastosowany zarówno do nadwyżkowych stóp zwrotu, jak i stałych regresji z modeli czynników.

\subsection{Testy odporności}

Autorzy przeprowadzili szereg czynności mających na celu sprawdzenie odporności uzyskanych wyników badania (robustness check). W pierwszej kolejności zbadano 4 alternatywne okresy formowania portfeli obejmujące 1, 3, 6 i 24 miesiące. Innymi słowy, okresy formowania rozpoczynają się odpowiednio w miesiącach $t-1, t-3, t$ -6 i $t-24$, a kończą w miesiącu $t-1$.

Po drugie, wykorzystano alternatywny model ważenia. Jak zauważono wcześniej, w badaniach na poziomie kraju powszechną praktyką jest stosowanie równoważonych indeksów w portfelu, gdyż przyjmuje się, że można to łatwo osiągnąć np. płynnymi kontraktami futures (zob. np. [Asness i in. 2013]). Niemniej autorzy są zdania, że tego rodzaju podejście może zaburzyć wyniki na co najmniej dwa sposoby. Po pierwsze, wskutek wpływu tak zwanej stopy zwrotu z dywersyfikacji (diversification return) [Willenbrock 2011]. Po drugie - wpływ emisji może być różny na rynkach małych i dużych. Dlatego też, stosując alternatywny model ważenia, autorzy jednocześnie pośrednio badają swoją drugą hipotezę dotyczącą rozbieżności wyników strategii opartej na emisjach na rynkach o różnych klasach wielkości rynku.

Po trzecie, autorzy bezpośrednio badają powyższą strategię na podzbiorach rynków małych i dużych. W tym celu utworzono posortowane portfele i przetestowano ich wyniki w ten sam sposób co wyniki portfeli sortowanych pojedynczo. Autorzy najpierw sortują rynki według łącznej kapitalizacji rynku akcji na koniec miesiąca $t-1$. Następnie dzielą próbę badawczą według mediany kapitalizacji i testują strategie na poszczególnych podzbiorach całej próby badawczej w taki sam sposób jak na całości próby. W celu zachowania spójności z wynikami sprawdzenia odporności alternatywnego modelu ważenia, który podkreśla znaczenie kapitalizacji, autorzy wykorzystują portfele ważone kapitalizacją również w tym podejściu.

Autorzy stosują dwie waluty bazowe: euro (EUR) i jena japońskiego (JPY). Innymi słowy wszystkie obliczenia wykonywane są ponownie, ale po przeliczeniu danych finansowych i rynkowych na EUR i JPY. W tym przypadku jednak autorzy nie wykryli istotnych odchyleń od podstawowych wyników w USD, toteż nie przedstawiają szczegółowo wyników procedury sprawdzania odporności w tym zakresie. 


\section{Wyniki i omówienie}

W tej części autorzy najpierw przedstawiają wyniki portfeli sortowanych pojedynczo według emisji, z podstawowymi i alternatywnymi okresami formowania i sposobami ważenia. Następnie przedstawione zostały nadwyżkowe stopy zwrotu z portfeli sortowanych podwójnie według emisji i łącznej kapitalizacji rynkowej.

W tabeli 1 przedstawiono nadwyżkowe stopy zwrotu z równoważonych portfeli sortowanych według emisji akcji. Uzyskane wyniki potwierdzają początkowe przypuszczenie autorów, tj. negatywny związek przyszłych stóp zwrotu z akcji z wcześniejszą aktywnością w zakresie emisji akcji. Nadwyżkowe stopy zwrotu w krajach z niższą aktywnością na rynku emisji są wyższe niż na rynkach, na których aktywność ta była wysoka. Średnia miesięczna nadwyżkowa stopa zwrotu z portfela zerowego wynosi 0,69\% i jest istotnie różna od zera. Wartość $p$ w teście $M R$ wynosi $0,3 \%$; istnieje zatem wyraźna relacja monotoniczna: im niższa aktywność na rynku emisji, tym wyższe stopy zwrotu. Dodatkowo wszystkie pięć portfeli pozycji dłu-

Tabela 1. Nadwyżkowe stopy zwrotu z portfeli sortowanych według emisji akcji

\begin{tabular}{|l|r|r|r|r|r|r|r|r|}
\hline & Wysoka & \multicolumn{1}{c|}{2} & \multicolumn{1}{c|}{3} & \multicolumn{1}{c|}{4} & Niska & $N-W$ & $M R$ & $G R S$ \\
\hline Średnia & 0,11 & 0,31 & 0,60 & $\mathbf{0 , 6 6 *}$ & $\mathbf{0 , 9 2 *}$ & $\mathbf{0 , 6 9 * *}$ & $\mathbf{0 , 3}$ & \\
\hline & $(0,18)$ & $(0,70)$ & $(1,36)$ & $\mathbf{( 1 , 7 0 )}$ & $\mathbf{( 1 , 8 6 )}$ & $\mathbf{( 1 , 9 6 )}$ & & \\
\hline $\begin{array}{l}\text { Odchylenie } \\
\text { standardowe }\end{array}$ & 6,78 & 6,01 & 5,77 & 5,87 & 6,35 & 4,65 & & \\
\hline Współczynnik Sharpe'a & 0,05 & 0,18 & 0,36 & 0,39 & 0,50 & 0,51 & & \\
\hline Najgorszy miesiąc & $-32,33$ & $-37,55$ & $-25,83$ & $-28,50$ & $-27,05$ & $-20,51$ & & \\
\hline Najlepszy miesiąc & 16,55 & 16,65 & 21,41 & 14,80 & 24,45 & 17,92 & & \\
\hline Skośność & $-1,15$ & $-1,57$ & $-0,54$ & $-1,02$ & $-0,30$ & $-0,53$ & & \\
\hline Kurtoza & 3,31 & 7,69 & 2,27 & 3,45 & 2,36 & 4,49 & & \\
\hline Stała regresji & $\mathbf{- 0 , 5 7 * *}$ & $-0,31$ & $-0,01$ & 0,06 & 0,25 & $0,67 * *$ & 0,2 & 4,8 \\
\hline & $\mathbf{( - 2 , 2 9 )}$ & $(-1,43)$ & $(-0,08)$ & $(0,37)$ & $(1,10)$ & $(\mathbf{2 , 1 1 )}$ & & \\
\hline
\end{tabular}

W tabeli przedstawiono podstawowe dane statystyczne nadwyżkowych stóp zwrotu równoważonych portfeli w poszczególnych kwintylach, posortowanych według emisji akcji w ostatnich 12 miesiącach. Portfel Niska zawiera $20 \%$ rynków akcji z najniższą aktywnością w zakresie emisji, a portfel Wysokie 20\% rynków akcji z najwyższą. $N$-W to portfel long/short, obejmujący pozycje długie w portfelu Niska i pozycje krótkie w portfelu Wysoka. Wyrazy wolne są wyrazami wolnymi z modelu czteroczynnikowego. MR i GRS oznaczają wartości $p$ odpowiadające testom relacji monotonicznej opisanym odpowiednio przez Pattona i Timmermanna [2010] oraz Gibbonsa i in. [1989]. Nadwyżkowe stopy zwrotu, odchylenia standardowe, miesiące najlepsze i najgorsze, stałe regresji i wartości $p$ zostały wyrażone w postaci procentowej. Liczby w nawiasach oznaczają statystyki $t$, a wartości istotne na poziomie $10 \%$ wyróżniono pogrubieniem. Symbolami * $\mathrm{i} * *$ wskazano wartości istotnie różne od 0 na poziomach odpowiednio $10 \%$ i $5 \%$.

Źródło: opracowanie własne na podstawie danych z bazy Bloomberga. 
gich charakteryzuje się porównywalnym poziomem ryzyka (mierzonym odchyleniem standardowym). W konsekwencji współczynniki Sharpe'a stale rosną wraz ze spadającym poziomem aktywności na rynku emisji.

Ponadprzeciętne wyniki rynków z niską aktywnością na rynku IPO w porównaniu z rynkami z wysoką aktywnością utrzymują się nawet po uwzględnieniu ryzyka rynkowego oraz międzyrynkowych efektów wartości, wielkości i momentum. Szczególnie wysoką wartość absolutną ma stała regresji w modelu czteroczynnikowym dla portfela o najniższej aktywności w zakresie emisji: wynosi ona $0,57 \%$ $i$ jest istotnie różna od zera. Alfa w modelu czteroczynnikowym dla portfela zerowego wynosi $0,67 \%$ i również jest istotnie różna od zera. Hipoteza zerowa testu GRS zostaje odrzucona, a zatem portfele sortowane według emisji istotnie podwyższają granicę efektywną inwestora globalnego stosującego strategie wartości, wielkości i momentum. Wreszcie wyniki testów $M R$ sugerują wyraźną monotoniczność na poziomie zarówno nadwyżkowych stóp zwrotu, jak i stałych regresji. Innymi słowy nadwyżkowe stopy zwrotu stale rosną wraz ze zmniejszaniem się aktywności w zakresie emisji. Powyższe wnioski są spójne z podobnymi badaniami prowadzonymi w odniesieniu do akcji przez Bakera i Wurglera [2000] lub Pontiffa i Woodgate'a [2008].

Co ciekawe, wielkość efektu emisji jest względnie duża w porównaniu z innymi anomaliami na poziomie kraju. Zaremba i Konieczka [2016] zbadali 16 międzyrynkowych strategii wyboru kraju i jedynie w dwóch przypadkach (strategie oparte na dźwigni i obrotach) uzyskane nadwyżkowe stopy zwrotu z portfeli zerowych były wyższe niż stopy zwrotu z portfela zaprezentowanego w tab. 1. Co więcej, strategia bazująca na emisjach uzyskuje lepsze wyniki niż wszystkie strategie bazujące na sprawdzanych w badaniu przez Zarembę [2015b] tradycyjnych czynnikach wartości, wielkości i momentum.

$\mathrm{W}$ tabeli 2 podano wyniki portfeli bazujących na emisjach $\mathrm{z}$ alternatywnymi okresami formowania. Każdy wybór okresu sortowania stanowi swoisty kompromis. $Z$ jednej bowiem strony okres krótszy bazuje na świeższych danych, powinien zatem lepiej oddawać nastroje na rynku. $\mathrm{Z}$ drugiej z kolei - na okresy bardzo krótkie istotny wpływ wywierają miesięczne wahania danych IPO, których charakter może być losowy. Wadę tę można częściowo skorygować uśrednianiem szeregów czasowych, podobnie jak w niniejszym badaniu. Początkowy wybór 12-miesięcznego okresu formowania jest czysto arbitralny, toteż w tab. 2 przedstawiono wyniki uzyskane po przyjęciu alternatywnych okresów formowania. Strategia wyboru kraju, bazująca na emisji, sprawdza się najlepiej w przypadku okresów długich. W przypadku okresów od 6 do 24 miesięcy portfele krajowe posortowane według emisji wykazują rozkłady podobne do wyników w tab. 1. Zarówno hipoteza zerowa testu $M R$, jak i GRS została istotnie odrzucona. Oznacza to, że granica efektywna jest podwyższona, a nadwyżkowe stopy zwrotu i stałe regresji zwiększają się równomiernie wraz z malejącą aktywnością w zakresie emisji. Co więcej, w obu przypadkach (sortowanie według okresu 6 i 24 miesiące od IPO) nadwyżkowe stopy zwrotu i alfy w modelu cztero- 
Tabela 2. Nadwyżkowe stopy zwrotu z portfeli sortowanych według emisji akcji $\mathrm{z}$ alternatywnymi okresami formowania

\begin{tabular}{|c|c|c|c|c|c|c|c|c|}
\hline & Wysoka & 2 & 3 & 4 & Niska & $N-W$ & $M R$ & $G R S$ \\
\hline \multicolumn{9}{|c|}{ miesięczny okres formowania } \\
\hline \multirow[t]{2}{*}{ Średnia } & 0,14 & 0,40 & 0,50 & $1,03 * *$ & 0,63 & 0,42 & 83,5 & \\
\hline & $(0,31)$ & $(0,98)$ & $(1,18)$ & $(2,11)$ & $(1,40)$ & $(1,63)$ & & \\
\hline Odchylenie standardowe & 6,05 & 5,79 & 5,95 & 6,24 & 6,08 & 3,52 & & \\
\hline Współczynnik Sharpe’a & 0,08 & 0,24 & 0,29 & 0,57 & 0,36 & 0,42 & & \\
\hline \multirow[t]{2}{*}{ Stała regresji } & $-0,48 * *$ & $-0,21$ & $-0,14$ & $0,39 *$ & $-0,04$ & 0,38 & 81,9 & 6,9 \\
\hline & $(-2,24)$ & $(-1,06)$ & $(-0,67)$ & $(1,76)$ & $(-0,15)$ & $(1,55)$ & & \\
\hline \multicolumn{9}{|c|}{ 3-miesięczny okres formowania } \\
\hline \multirow[t]{2}{*}{ Średnia } & 0,23 & 0,33 & 0,57 & 0,64 & $0,95^{*}$ & $0,66 * *$ & 0,3 & \\
\hline & $(0,49)$ & $(0,78)$ & $(1,40)$ & $(1,48)$ & $(1,93)$ & $(2,00)$ & & \\
\hline Odchylenie standardowe & 6,06 & 5,94 & 5,99 & 5,80 & 6,42 & 4,04 & & \\
\hline Współczynnik Sharpe’a & 0,13 & 0,19 & 0,33 & 0,38 & 0,51 & 0,56 & & \\
\hline \multirow[t]{2}{*}{ Stała regresji } & $-0,39^{*}$ & $-0,29$ & $-0,06$ & 0,04 & 0,27 & $0,59 * *$ & $\mathbf{0 , 3}$ & 28,5 \\
\hline & $(-1,75)$ & $(-1,49)$ & $(-0,23)$ & $(0,31)$ & $(1,14)$ & $(2,13)$ & & \\
\hline \multicolumn{9}{|c|}{ 6-miesięczny okres formowania } \\
\hline \multirow[t]{2}{*}{ Średnia } & 0,02 & 0,40 & 0,67 & $0,67 *$ & $0,91 *$ & $0,80 * *$ & 2,9 & \\
\hline & $(0,02)$ & $(0,94)$ & $(1,55)$ & $(1,67)$ & $(1,76)$ & $(2,28)$ & & \\
\hline Odchylenie standardowe & 6,41 & 5,92 & 5,97 & 5,73 & 6,40 & 4,42 & & \\
\hline Współczynnik Sharpe’a & 0,01 & 0,23 & 0,39 & 0,40 & 0,49 & 0,62 & & \\
\hline \multirow[t]{2}{*}{ Stała regresji } & $-0,64 * *$ & $-0,2$ & 0,03 & 0,06 & 0,24 & $0,78 * *$ & 1,6 & 4,9 \\
\hline & $(-2,68)$ & $(-0,92)$ & $(0,20)$ & $(0,30)$ & $(1,08)$ & $(2,60)$ & & \\
\hline \multicolumn{9}{|c|}{ 24-miesięczny okres formowania } \\
\hline \multirow[t]{2}{*}{ Średnia } & 0,07 & 0,24 & 0,65 & $0,79 *$ & $0,85^{*}$ & $0,60 *$ & 0,7 & \\
\hline & $(0,10)$ & $(0,55)$ & $(1,57)$ & $(1,94)$ & $(1,74)$ & $(1,68)$ & & \\
\hline Odchylenie standardowe & 6,91 & 6,25 & 5,79 & 5,65 & 6,40 & 5,02 & & \\
\hline Współczynnik Sharpe’a & 0,03 & 0,14 & 0,39 & 0,48 & 0,46 & 0,44 & & \\
\hline \multirow[t]{2}{*}{ Stała regresji } & $-0,61 * *$ & $-0,37$ & 0,01 & 0,20 & 0,17 & $0,61 * *$ & 4,4 & 3,7 \\
\hline & $(-2,34)$ & $(-1,58)$ & $(0,04)$ & $(1,18)$ & $(0,89)$ & $(2,12)$ & & \\
\hline
\end{tabular}

W tabeli przedstawiono podstawowe dane statystyczne dotyczące nadwyżkowych stóp zwrotu równoważonych portfeli w poszczególnych kwintylach, posortowanych według emisji akcji w okresie ostatnich 1-24 miesięcy. Niska zawiera 20\% rynków akcji z najniższą aktywnością w zakresie emisji, a portfel Wysokie 20\% rynków akcji z najwyższą. N-W to portfel long/short, obejmujący pozycje długie w portfelu Niska i pozycje krótkie w portfelu Wysoka. Wyrazy wolne są wyrazami wolnymi z modelu czteroczynnikowego. $M$ i GRS oznaczają wartości $p$ odpowiadające testom relacji monotonicznej opisanym odpowiednio przez Pattona i Timmermanna [2010] oraz Gibbonsa i in. [1989]. Nadwyżkowe stopy zwrotu, odchylenia standardowe, stałe regresji i wartości $p$ zostały wyrażone w postaci procentowej. Liczby w nawiasach oznaczają statystyki $t$, a wartości istotne na poziomie 5\% wyróżniono pogrubieniem. Symbolami * $\mathrm{i} * *$ wskazano wartości istotnie różne od 0 na poziomach odpowiednio $10 \%$ i $5 \%$.

Źródło: opracowanie własne na podstawie danych z bazy Bloomberga. 
czynnikowym z portfela zerowego są dodatnie i istotnie różne od zera. W przypadku 6 miesięcy faktyczny wynik portfela zerowego jest nawet lepszy niż w przypadku okresu 12 -miesięcznego. Nadwyżkowe stopy zwrotu wynoszą tu $0,80 \%$, a stała regresji $0,78 \%$ (obie wartości są istotnie różne od zera).

Jeśli wziąć pod uwagę krótsze okresy formowania (od 1 do 3 miesięcy), wyniki nie są tak imponujące i przekonujące. Test GRS nie został odrzucony w żadnym z dwóch przypadków. Niemniej jednak nawet w okresie tak krótkim jak trzymiesięczny portfel zerowy cechuje się dodatnią średnią nadwyżkową stopą zwrotu i stałą regresji istotnie różną od zera, a wartość $p$ w teście $M R$ wynosi $0,3 \%$.

Alternatywny model ważenia bazujący na kapitalizacjach poszczególnych rynków przedstawiony został $\mathrm{w}$ tab. 3 .

Tabela 3. Wpływ modelu ważenia kapitalizacją na nadwyżkowe stopy zwrotu z portfeli sortowanych według emisji akcji

\begin{tabular}{|l|r|r|r|r|r|r|r|r|}
\hline & Wysoka & \multicolumn{1}{|c|}{2} & \multicolumn{1}{c|}{3} & \multicolumn{1}{c|}{4} & Niska & $N-W$ & $M R$ & GRS \\
\hline Średnia & 0,21 & 0,15 & 0,44 & 0,56 & 0,71 & 0,43 & 5,2 & \\
\hline & $(0,42)$ & $(0,50)$ & $(1,10)$ & $(1,44)$ & $(0,95)$ & $(0,66)$ & & \\
\hline $\begin{array}{l}\text { Odchylenie } \\
\text { standardowe }\end{array}$ & 6,25 & 5,54 & 5,80 & 6,43 & 8,97 & 7,64 & & \\
\hline $\begin{array}{l}\text { Współczynnik } \\
\text { Sharpe’a }\end{array}$ & 0,11 & 0,10 & 0,26 & 0,30 & 0,27 & 0,19 & & \\
\hline Stała regresji & $-0,38$ & $-0,36$ & $-0,14$ & $-0,03$ & $-0,10$ & 0,21 & 8,6 & 62,1 \\
\hline & $(-1,50)$ & $(-1,43)$ & $(-0,63)$ & $(-0,11)$ & $(-0,42)$ & $(0,41)$ & & \\
\hline
\end{tabular}

W tabeli przedstawiono podstawowe dane statystyczne dotyczące nadwyżkowych stóp zwrotu z portfeli ważonych kapitalizacją w poszczególnych kwintylach, posortowanych według emisji akcji w ostatnich 12 miesiącach. Niska zawiera 20\% rynków akcji z najniższą aktywnością w zakresie emisji, a portfel Wysokie 20\% rynków akcji z najwyższą. $N$-W to portfel long/short, obejmujący pozycje długie w portfelu Niska i pozycje krótkie w portfelu Wysoka. Wyrazy wolne są wyrazami wolnymi z modelu czteroczynnikowego. MR i GRS oznaczają wartości $p$ odpowiadające testom relacji monotonicznej opisanym odpowiednio przez Pattona i Timmermanna [2010] oraz Gibbonsa i in. [1989]. Nadwyżkowe stopy zwrotu, odchylenia standardowe, stałe regresji i wartości $p$ zostały wyrażone w postaci procentowej. Liczby w nawiasach oznaczają statystyki $t$, a wartości istotne na poziomie 5\% wyróżniono pogrubieniem. Symbolami $* \mathrm{i} * *$ wskazano wartości istotnie różne od 0 na poziomach odpowiednio $10 \%$ i $5 \%$.

Źródło: opracowanie własne na podstawie danych z bazy Bloomberga.

Zgodnie z oczekiwaniami wyniki strategii bazującej na emisji są przy zastosowaniu tego podejścia znacznie mniej imponujące niż przy stosowaniu równoważenia. Aczkolwiek rynki z niską aktywnością w zakresie emisji cechują się wyższymi współczynnikami Sharpe’a niż rynki z wysoką aktywnością, a wyniki nie są statystycznie istotne. Co ciekawe, portfel z niską aktywnością na rynku IPO jest portfelem najbardziej ryzykownym; odchylenie standardowe stóp zwrotu wynosi tu 
$8,97 \%$. Hipotezy zerowe testu MR zostały odrzucone jedynie na poziomie $10 \%$, a nie 5\%. Średnie nadwyżkowe stopy zwrotu z portfela long/short wynoszą jedynie $0,43 \%$, a alfa $0,21 \%$. Obie wartości nie są istotnie różne od zera.

Gorsze wyniki portfela ważonego kapitalizacją w porównaniu z portfelem równoważonym wyjaśnić można różnicami przekrojowymi wyników poszczególnych klas wielkości badanych rynków. Kwestia ta została zbadana szczegółowo w tab. 4. Aby zachować spójność z wynikami w tab. 3, również w tym przypadku zastosowano model ważenia kapitalizacją.

Tabela 4. Nadwyżkowe stopy zwrotu z portfeli podwójnie sortowanych według emisji akcji i łącznej kapitalizacji rynkowej

\begin{tabular}{|c|c|c|c|c|c|c|c|c|}
\hline & Wysoka & 2 & 3 & 4 & Niska & $N-W$ & $M R$ & GRS \\
\hline \multicolumn{9}{|c|}{ Tylko duże rynki } \\
\hline \multirow[t]{2}{*}{ Średnia } & 0,14 & 0,44 & 0,34 & 0,57 & 0,74 & 0,60 & 7,3 & \\
\hline & $(0,39)$ & $(1,09)$ & $(0,73)$ & $(1,26)$ & $(1,07)$ & $(1,06)$ & & \\
\hline $\begin{array}{l}\text { Odchylenie } \\
\text { standardowe }\end{array}$ & 5,86 & 5,76 & 6,53 & 7,05 & 8,72 & 6,49 & & \\
\hline Współczynnik Sharpe’a & 0,09 & 0,27 & 0,18 & 0,28 & 0,29 & 0,32 & & \\
\hline \multirow[t]{2}{*}{ Stała regresji } & $-0,41$ & $-0,11$ & $-0,26$ & $-0,12$ & $-0,09$ & 0,31 & 16,1 & 62,0 \\
\hline & $(-1,52)$ & $(-0,43)$ & $(-0,82)$ & $(-0,40)$ & $(-0,50)$ & $(0,69)$ & & \\
\hline \multicolumn{9}{|c|}{ Tylko małe rynki } \\
\hline \multirow[t]{2}{*}{ Średnia } & $-0,42$ & 0,44 & 0,79 & 0,56 & 1,03 & $1,14 * *$ & 18,7 & \\
\hline & $(-0,81)$ & $(0,91)$ & $(1,62)$ & $(1,20)$ & $(1,79)$ & $(2,41)$ & & \\
\hline $\begin{array}{l}\text { Odchylenie } \\
\text { standardowe }\end{array}$ & 7,86 & 6,91 & 7,29 & 6,75 & 7,24 & 7,49 & & \\
\hline Współczynnik Sharpe’a & $-0,19$ & 0,22 & 0,37 & 0,29 & 0,49 & 0,53 & & \\
\hline \multirow[t]{2}{*}{ Stała regresji } & $-1,15^{* *}$ & $-0,22$ & 0,12 & $-0,08$ & 0,40 & $1,20 * *$ & 8,7 & 2,9 \\
\hline & $(-3,25)$ & $(-0,82)$ & $(0,36)$ & $(-0,24)$ & $(1,15)$ & $(2,19)$ & & \\
\hline
\end{tabular}

W tabeli przedstawiono podstawowe dane statystyczne dotyczące nadwyżkowych stóp zwrotu z portfeli ważonych kapitalizacją, posortowanych podwójnie według emisji akcji w poprzednich 12 miesiącach i łącznej kapitalizacji rynku. Niska zawiera $20 \%$ rynków akcji z najniższą aktywnością w zakresie emisji, a portfel Wysokie $20 \%$ rynków akcji z najwyższą. $N$ - $W$ to portfel long/short, obejmujący pozycje długie w portfelu Niska i pozycje krótkie w portfelu Wysoka. Wyrazy wolne są wyrazami wolnymi z modelu czteroczynnikowego. $M R$ i $G R S$ oznaczają wartości $p$ odpowiadające testom relacji monotonicznej opisanym odpowiednio przez Pattona i Timmermanna [2010] oraz Gibbonsa i in. [1989]. Nadwyżkowe stopy zwrotu, odchylenia standardowe, stałe regresji i wartości $p$ zostały wyrażone w postaci procentowej. Liczby w nawiasach oznaczają statystyki $t$, a wartości istotne na poziomie $5 \%$ wyróżniono pogrubieniem. Symbolami $* \mathrm{i} * *$ wskazano wartości istotnie różne od 0 na poziomach odpowiednio $10 \%$ i $5 \%$.

Źródło: opracowanie własne na podstawie danych z bazy Bloomberga. 
Zgodnie z hipotezą autorów anomalia emisyjna jest o wiele silniejsza na rynkach małych niż dużych. Jeśli wziąć pod uwagę rynki duże, efekt ten praktycznie nie występuje. Nie wykryto żadnych znaczących alf portfela zerowego, a statystyki testów $G R S$ i $M R$ nie są istotne. Z kolei w przypadku małych rynków omawiany efekt występuje w niektórych sytuacjach z jeszcze większą intensywnością niż w całości próby badawczej. Średnie nadwyżkowe stopy zwrotu i alfa portfela zerowego są równe odpowiednio 1,14\% i 1,20\% (obie wielkości są istotnie różne od zera). Szczególnie słabo wypadł wynik portfela z najwyższą aktywnością na rynku emisji. Alfa modelu czteroczynnikowego jest istotnie ujemna i wynosi $-1,15 \%$. Wartość $p$ w teście $G R S$ wynosi zaledwie 2,9\%, czyli mniej niż wszystkie inne wartości $p$ odpowiadające strategiom badanym w całej próbie badawczej i opisanym w tab. 1 i 2 . Należy jednak wskazać, że testy $M R$ nie do końca wyraźnie wskazują na monotoniczność wyników małych rynków. Autorzy są jednak zdania, że do rezultatów tych należy podchodzić ostrożnie, gdyż stopy zwrotu z portfeli sortowanych według małych rynków są bardziej płynne (miesięczne odchylenia standardowe od $6,75 \%$ do $7,86 \%$ ), zatem moc testu $M R$ jest niższa niż w przypadku portfeli utworzonych z całej próby badawczej.

\section{Wnioski końcowe}

W niniejszym artykule przedstawiono powiązania między wpływem aktywności w zakresie emisji akcji na poziomie kraju a oczekiwanymi przyszłymi stopami zwrotu. Wykazano, że rynki z dużą aktywnością emisji na rynku akcji cechują się niższymi stopami zwrotu niż rynki z niską aktywnością. Efekt ten wykazuje odporność na zmiany w okresie formowania i waluty bazowej, jednak jego wielkość jest różna w zależności od kapitalizacji rynku. Na rynkach małych jest on bardzo silny, lecz na dużych nie ma większego znaczenia. Uzyskane przez autorów wyniki są zbieżne z koncepcjami behawioralnymi Lee i in. [1991] i Lowry [2003], którzy twierdzą, że zbyt duża liczba IPO, będąca oznaką zbytniego optymizmu inwestorów, może być zbieżna z nadmierną wyceną rynku akcji.

Należy jednak podkreślić, że na wyniki niniejszego badania wpływają dwa potencjalnie istotne ograniczenia. Po pierwsze, badany okres obejmuje lata globalnego kryzysu finansowego. Fakt ten może zniekształcić uzyskane wnioski w trudny do ocenienia sposób. Innymi słowy, wyniki mogą być w pewnej mierze specyficzne dla danego okresu. Po drugie, w badaniu nie uwzględniono kosztów transakcyjnych ani ograniczeń płynności, które mogą obniżyć zyskowność strategii wyboru kraju bazującej na emisji.

Z uzyskanych wyników płyną istotne wnioski dla inwestorów, osób zarządzających aktywami i osób wybierających fundusze. Po pierwsze, aktywność w zakresie emisji na badanych rynkach może posłużyć do skonstruowania cennego narzędzia dla globalnych inwestorów korzystających z pasywnych produktów inwestycyjnych rynku akcji, takich jak fundusze ETF i indeksowe. Po drugie, przedstawione strate- 
gie oparte na czynnikach mogą stosować również osoby zarządzające inwestycjami w tradycyjny sposób. Po trzecie, skoro aktywność w zakresie emisji jest wiarygodnym wskaźnikiem spodziewanych przyszłych stóp zwrotu, można ją wykorzystać w modelu wyceny aktywów i skutecznie zastosować do wyceniania międzynarodowych strategii inwestycyjnych o zasięgu globalnym.

Dalsze badanie kwestii poruszonych w niniejszym artykule mogłoby odbywać się na wiele sposobów. Po pierwsze, jedną z wad przeprowadzonych obliczeń jest pominięcie funkcji kosztów oraz ograniczeń płynności i mobilności kapitału. Aspekty te należałoby zbadać dodatkowo w kolejnych badaniach, zwłaszcza że mogą one częściowo wyjaśniać opisywane efekty. Po drugie, zbadać należałoby wpływ niektórych kwestii specyficznych dla danego rynku, na przykład poziom rozwoju rynku, integracji, struktury lub otwartości inwestorów. Po trzecie, cenny wkład stanowiłoby badanie interakcji między efektem emisji i innymi anomaliami na poziomie kraju, np. powiązanymi z wartością, wielkością, momentum, jakością lub ryzykiem. Po czwarte, Jacobs [2015] w swoim najnowszym artykule zbadał kwestię, czy anomalii na poziomie akcji nie należałoby raczej wyjaśniać zmiennymi w czasie ograniczeniami arbitrażu lub nastrojów. Powtórzenie tego badania na poziomie kraju byłoby bardzo cenne i mogłoby dodatkowo potwierdzić, czy uzyskane przez autorów wyniki są pochodną nastrojów. Niemniej jednak tego rodzaju badanie uzależnione jest od ustalenia globalnych wskaźników dla ograniczeń arbitrażu i nastroju inwestorów.

\section{Literatura}

Asness C.S., Moskowitz T.J., Pedersen L.H., 2013, Value and momentum everywhere, Journal of Finance, vol. 68, s. 929-985.

Baker M., Wurgler J., 2000, The equity share in new issues and aggregate stock returns, Journal of Finance, vol. 55, s. 2219-2258.

Bali C., Cakici N., Fabozzi F., 2013, Book-to-market and the cross-section of expected stock returns in international stock markets, Journal of Portfolio Management, vol. 39, s. 101-115.

Balvers R., Wu, Y., 2006, Momentum and mean reversion across national equity markets, Journal of Empirical Finance, vol. 13, s. 24-48.

Bekaert G., Harvey C.R., 2000, Foreign speculators and emerging equity markets, Journal of Finance, vol. 55 , s. 565-613.

Bekaert G., Harvey C., Lundblad C., 2007, Liquidity and expected returns: Lessons from emerging markets, Review of Financial Studies, vol. 20, s. 1783-1831.

Bhojraj S., Swaminathan B., 2006, Macromomentum: Returns predictability in international equity indices, Journal of Business, vol. 79, s. 429-451.

Brown A., Du D.Y., Rhee S.G., Zhang L., 2008, The returns to value and momentum in Asian markets, Emerging Markets Review, vol. 9, s. 79-88.

Campbell C.J., Rhee S.G., Du Y., Tang N., 2008, Market sentiment, IPO underpricing, and valuation. Working paper dostępny w SSRN: http://ssrn.com/abstract=1108540 lub http://dx.doi.org/10.2139/ ssrn. 1108540 . 
Carhart M.M., 1997, On persistence in mutual fund performance, Journal of Finance, vol. 52, s. 57-82. Cochrane J.C., 2001, Asset Pricing, Princeton University Press, Princeton.

Dorn D., 2009, Does sentiment drive the retail demand for IPOs?, Journal of Financial and Quantitative Analysis, vol. 44, s. 85-108.

De Moor L., Sercu P., 2013, The smallest firm effect: An international study, Journal of International Money and Finance, vol. 32, s. 129-155.

Fama E.F., French K.R., 2012, Size, value, and momentum in international stock returns, Journal of Financial Economics, vol. 105, s. 457-472.

Gibbons M.R., Ross S.A., Shanken J., 1989, A test of the efficiency of a given portfolio, Econometrica, vol. 57, s. 1121-1152.

Goetzmann W., Li L., Rouwenhorst G., 2005, Long-term global market correlations, Journal of Business, vol. 78, s. 1-38.

Greenwood R., Hanson S.G., 2012, Share issuance and factor timing, Journal of Finance, vol. 68, s. 761-798.

Harvey C.R., Liu Y., Zhu H., 2015, .... and the cross-section of expected returns, Working paper dostępny w SSRN: http://ssrn.com/abstract=2249314 lub http://dx.doi.org/10.2139/ssrn.2249314 [dostęp 12 kwietnia 2015].

Hester W., 2013, Fed leaves punchbowl, takes away free lunch, of international diversification, Hausman Funds Investment Research and Insight, http://www.hussmanfunds.com/rsi/intldiversification.htm [dostęp 8 listopada 2014].

Jacobs H., 2015, What explains the dynamics of 100 anomalies?, Journal of Banking and Finance, vol. 57 , s. 65-85.

Keppler M., Encinosa P., 2011, The small-country effect revisited, Journal of Investing, vol. 20, s. 99-103.

Keppler M., Traub H., 1993, The small-country effect: Small markets beat large markets, Journal of Investing, vol. 2, s. 17-24.

Kim D., 2012, Value premium across countries, Journal of Portfolio Management, vol. 38, s. 75-86.

Lee C.M.C., Shleifer A., Thaler R.H., 1991, Investor sentiment and the closed-end fund puzzle, Journal of Finance, vol. 46, s. 75-109.

Liew J., Vassalou M., 2000, Can book-to-market, size and momentum be risk factors that predict economic growth?, Journal of Financial Economics, vol. 57, s. 221-245.

Liu M., Liu Q., Ma T., 2011, The 52-week high momentum strategy in international stock markets, Journal of International Money and Finance, vol. 30, s. 180-204.

Ljungqvist A., Nanda V., Singh R., 2006, Hot markets, investor sentiment, and IPO pricing, Journal of Business, vol. 79, s. 1667-1702.

Lowry M., 2003, Why does IPO volume fluctuate so much?, Journal of Financial Economics, vol. 67, s. 3-40.

Macedo R., 1995, Country-Selection Style, [w:] Lederman J., Klein R.A. (red.), Equity Style Management: Evaluating and Selecting Investment Styles, Irwin Professional Publishing, Burr Ridge.

MSCI, 2014a, MSCI Global Market Accessibility Review, http:/www.msci.com/resources/products/ indexes/global_equity_indexes/gimi/stdindex/MSCI_Global_Market_Accessibiliy_Review_ June2014.pdf [dostęp 1 listopada 2014].

MSCI, 2014b, MSCI Global Investable Market Indexes Methodology, http://www.msci.com/eqb/methodology/meth_docs/MSCI_Aug14_GIMIMethod.pdf [dostęp 1 listopada 2014].

Patton A.J., Timmermann A., 2010, Monotonicity in asset returns, new tests with applications to the term structure, the CAPM and portfolio sorts, Journal of Financial Economics, vol. 98, s. 605-625.

Pontiff J., Woodgate A., 2008, Share issuance and cross-sectional returns, Journal of Finance, vol. 63, s. 921-45.

Quinn D.P., Voth H.J., 2008, Century of stock market correlations and international financial openness, American Economic Review, vol. 98, s. 529-534. 
Willenbrock S., 2011, Diversification return, portfolio rebalancing, and the commodity return puzzle, Financial Analyst Journal, vol. 67, s. 42-49.

Zaremba A., 2015a, Country selection strategies based on quality, Managerial Finance, vol. 41, s. $1336-1356$.

Zaremba A., 2015b, Country selection strategies based on value, size and momentum, Investment Analyst Journal, vol. 44, s. 171-198.

Zaremba A., Konieczka P., 2016, Do quantitative country selection strategies really work?, Journal of Investment Strategies, vol. 5, no. 1, s. 1-33. 